\title{
A LEITURA EM TELAS \\ UM CONVITE À REFLEXÃO EM TEMPOS PANDÊMICOS ${ }^{1}$
}

\section{ENTREVISTA COM ROGER CHARTIER CONCEDIDA A LUZMARA CURCINO}

\author{
READING, MORE THAN EVER, ON SCREENS \\ AN INVITATION TO CRITICAL REFLECTION IN PANDEMIC TIMES \\ INTERVIEW WITH ROGER CHARTIER GRANTED TO LUZMARA CURCINO
}

\section{RESUMO}

Nesta entrevista, Roger Chartier nos ajuda a decifrar, à luz da história, aspectos do presente relativos às práticas de escrita e de leitura, com reflexões dedicadas à escola, à biblioteca, à livraria, ao livro, à prática cultural da leitura e aos leitores infantis e juvenis, relacionadas ao contexto peculiar de expansão das tecnologias digitais de produção e de acesso aos textos, de ampliação da circulação de falsificações e da crença nessas falsificações, por fim, de intensificação das crises em função do cenário de pandemia, em especial no que diz respeito à sobrevivência das livrarias. Nunca estivemos tanto tempo diante de telas, lendo textos, nos comunicando, jogando ou assistindo a vídeos. Mais do que um simples meio, as telas nos confrontam a uma outra lógica, desde a da concepção de produções que não podem mais simplesmente serem chamadas de livros, passando pelos usos impacientes que têm caracterizado nossas práticas de leitura, até a necessária reflexão das formas de consumo virtuais e de aquisição de livros por meio de gestos aparentemente inócuos como o do click, mas prenhes de implicações, tal como nos apresenta o historiador.

Palavras-chave: Livro; Leitura; Novas Tecnologias; Pandemia; História Cultural.

\begin{abstract}
In this interview, Roger Chartier helps us to decipher, in the light of history, aspects of the present related to the practices of writing and reading, with reflections dedicated to the school, the library, the bookstore, the book, the cultural practice of reading and the readers children and youth, related to the peculiar context of the expansion of digital production technologies and access to texts, the expansion of the circulation of fake news, finally, the intensification of crises due to the pandemic scenario, especially about bookstores. We have never been in front of screens so long, reading texts, communicating, playing games or watching videos. More than a simple means, they confront us with another logic, from the conception of productions that can no longer simply be called books, through the impatient uses that have characterized our reading practices, to the necessary reflection of the forms of virtual consumption and the acquisition of books through apparently innocuous gestures such as clicking, but full of implications.
\end{abstract} Keywords: Book; Reading; New Technologies; Pandemic; Cultural History.

1 Entrevista com Roger Chartier (EHESS / Collège de France) concedida a Luzmara Curcino (UFSCar) no dia 20 de abril de 2021, realizada a convite de Ana Maria Esteves Bortolanza, com vistas a sua publicação neste dossiê temático Leitura e escrita na educação básica: Interfaces teoria e prática, da Revista Brasileira de Alfabetização vinculada à ABALF-Associação Brasileira de Alfabetização. Esta entrevista registrada audiovisualmente foi transcrita por Andrei Cezar da Silva, (mestrando do PPGL-UFSCar) e retextualizada pela entrevistadora. 


\section{Introdução}

Luzmara Curcino: Gostaria de iniciar esta entrevista manifestando meu profundo respeito e solidariedade às famílias das milhares de vítimas da COVID no Brasil e no mundo. Nossa solidariedade vem acompanhada de um sentimento de profunda tristeza por essas perdas irreparáveis, mas também da certeza de nosso compromisso como professores com a reflexão científica, com a crítica política e com a aposta de que a educação é a forma mais eficaz de promoção de uma sociedade mais igualitária, justa e democrática. Como sabemos, a COVID afeta a todos em todos os lugares do mundo, mas não indistintamente. Em países como o Brasil, os mais atingidos são, sem dúvida, as classes dos trabalhadores e das trabaIhadoras que todos os dias enfrentam ônibus e metrôs lotados para chegar ao serviço ou para realizarem qualquer tipo de "bico", diante do desemprego que nos assola. São eles também que residem em casas pequenas, muitas vezes sem água encanada ou energia elétrica e que mais adoecem e morrem, vítimas da falta e do tipo de informação a que estão expostos, do descaso político com ações efetivas de prevenção e cuidados, enfim, da indiferença em relação a suas vidas que aos olhos da atual presidência de nosso país, inapta e negacionista, são vidas que valem menos do que "o mercado", do que "a economia".

É em função de nosso compromisso profissional com a ciência, e ético na promoção de uma sociedade mais justa, instruída e protegida cultural e politicamente dos engodos e das falsas notícias que se multiplicam entre nós, que muito nos honra entrevistar o professor Roger Chartier, historiador reconhecido internacionalmente por seu trabalho com a história da cultura escrita ocidental, como especialista da história do livro e, sobretudo, da história da leitura e dos leitores populares. Suas reflexões são conhecidas em campos de saber bastante variados, da história aos estudos literários, da educação à ciência da informação, da sociologia aos estudos linguísticos, para citar alguns desses campos. É um pesquisador muito respeitado no Brasil pela força teórica de suas reflexões, por sua brilhante trajetória acadêmica e de pesquisa e por sua acolhida atenciosa, ao longo de décadas, de muitos pesquisadores brasileiros, na EHESS - Escola de Altos Estudos em Ciências Sociais, e depois no Collège de France, bem como por sua participação generosa e incansável em sucessivos eventos aqui deste lado do Atlântico. Por essas razões, trata-se de um autor incontornável para os pesquisadores e estudiosos da leitura, para os professores e outros especialistas mediadores dessa prática. Mesmo em tempos pandêmicos e de isolamento social, o professor não tem se furtado em aceitar os convites para intervenções remotas, por meio das novas tecnologias, que são também tema desta entrevista, de modo a manter o diálogo sempre bem-vindo, e constante, apesar das distâncias do espaço físico e das diferenças de fuso-horário. Nosso muito obrigada.

Roger Chartier: Muito obrigado pela apresentação e muito obrigado pelo convite. É um prazer compartilhar esse momento com vocês.

Luzmara Curcino: Poderíamos iniciar esta entrevista, retomando as palavras de Donald McKenzie que o professor cita, afetuosamente, com alguma frequência. Ele nos diz: "Novos leitores criam novos textos cujas significações dependem diretamente de suas novas formas". Esta citação sintetiza uma reflexão histórica e hermenêutica muito potente e, tal como o senhor reitera em seus livros, não podemos ignorar os efeitos do tempo sobre um texto, sobre sua existência material e simbólica, assim como sobre as formas de suas apropriações pelos leitores. Algumas dessas mudanças nas formas dos textos são mais sutis, outras, no entanto, podem ser mais sensíveis, variadas e complexas, como no caso das adaptações de obras. As adaptações nos colocam diante de novas formas de um mesmo texto destinadas a novos leitores. Considerando que as adaptações correspondem, hoje, a um segmento editorial de peso, especialmente, junto ao público infantil e juvenil, gostaria de ouvi-lo acerca dessas transformações históricas, materiais, de público a que certos textos estão suscetíveis no processo de sua adaptação. 
Roger Chartier: A meu ver, as adaptações são, de fato, uma ilustração privilegiada do que afirmou Donald McKenzie. Com elas se pode observar, simultaneamente, uma transformação da literalidade do texto adaptado, que é abreviado, recomposto, reescrito, e uma transformação de sua forma material, de sua inscrição, publicação e circulação. Essas transformações são geralmente realizadas para apresentá-lo a um novo público leitor, que pode ser 'novo' tanto por ser socialmente mais amplo quanto por se dirigir especificamente a um segmento de público com idade bem distinta daquela do leitor previsto pelo texto original. Além disso, a própria mudança da situação de recepção de um mesmo texto (em outro tempo, junto a um público distinto, para outras finalidades) implica transformações em sua leitura e interpretação.

Diante do amplo leque de considerações que se poderia fazer sobre este tema, eu apresentaria um esboço de uma tipologia para se abordar as adaptações. Para isso, vou tomar como exemplo uma obra à qual tenho me dedicado, mais que a outras, ao longo de minhas pesquisas. Refiro-me a "Dom Quixote de La Mancha", de Miguel de Cervantes.

Um primeiro tipo de adaptação que se pode levantar é aquele que diz respeito à mudança de gênero discursivo. Como vocês sabem, Dom Quixote é originalmente uma narração, um "romance", ainda que esse termo não fosse empregado no século XVII com o sentido que lhe atribuímos hoje em dia. O que importa é que boa parte do público dessa obra, tanto à sua época quanto ao longo dos séculos, travou contato com essa história sob uma forma distinta daquela em que ela veio à luz, escrita sobre o papel e concebida por seu autor para ser um 'livro' impresso, no início do século XVII. Desde então, muitos 'leitores' de Dom Quixote tiveram acesso a essa narrativa não por meio da leitura de um texto, mas por sua interpretação em um palco de teatro. Este é, portanto, um exemplo desse tipo de adaptação que se caracteriza pela transformação do gênero de origem de uma obra, do romance para o teatro, e com esta, de mudança de sua forma de circulação, das páginas ao palco. É interessante considerar ainda que as primeiras recepções das desventuras de Quixote, na Inglaterra, por exemplo, se deram frente a um palco. Tem-se notícia de uma adaptação teatral da narrativa de Cervantes para o público inglês pouco depois de seu lançamento na Espanha, e que foi assinada por John Fletcher e Willian Shakespeare, mas cujo texto infelizmente desapareceu, tornando assim mais difícil a pesquisa desse fato?

Essa mesma trajetória de circulação da obra que chega a muitos "leitores" graças a sua adaptação para o teatro deu-se como tal não apenas na Inglaterra, mas também na França assim como em Portugal. Em 1733, Antônio José da Silva produziu uma adaptação teatral da segunda parte de Dom Quixote para o teatro de bonifrates (teatro de bonecos) do Bairro Alto em Lisboa. Foi justamente essa adaptação teatral da segunda parte da narrativa cervantina a primeira tradução para o português do texto de Cervantes, já que a publicação em livro de sua tradução integral só seria lançada em $1794^{3}$. Este é, sem dúvida, um primeiro tipo de adaptação com o qual estamos bastante familiarizados hoje em dia, frente às adaptações de obras para filmes, séries, novelas de televisão. Este tipo, concernente à mudança de gênero, representa, sem dúvida, uma forma paroxística da adaptação.

A segunda classe de meu esboço de tipologia das adaptações seria a da adaptação como condensação do texto, aquela que se faz com o objetivo de encurtar textos longos. Novamente encontramos com a obra Dom Quixote um bom exemplo deste tipo de adaptação. Na segunda metade do século XVII, início do século XVIII, na Inglaterra, nos deparamos com essa longa narrativa em dois volumes, com esse romance em duas partes, publicado em uma versão small book, ou seja, circulando

2 A esse respeito, cf. Chartier, 2012a.

3 A esse respeito, cf. Chartier, 2012b. 
sob a forma de um pequeno livro de 24 páginas, formato in-duodécimo (12 folhas), semelhante àquele dos livros de bolso, formato, aliás, muito popular no repertório das obras comercializadas pelos vendedores ambulantes da literatura de colportage. Também se podia encontrar, nesse mesmo período, versões de Dom Quixote publicadas em outros formatos reduzidos, ainda que não tão breves como este de 24 páginas. Algumas adaptações reduzidas foram publicadas com 50, 100, ou 200 páginas, e tinham como característica propor ao leitor o que qualificavam como a "quintessência" do texto, ou seja, essas adaptações se apresentavam como uma condensação que garantia o acesso ao essencial do romance, segundo as palavras dos responsáveis pela publicação da versão reduzida. Outra versão desse tipo de adaptação, à época, também regulada pelo princípio da condensação do texto, e que oferecia o texto em formatos mais reduzidos, era aquela que apostou na divisão e na circulação da narrativa em fascículos.

Esta segunda forma da adaptação, a da redução da narrativa, é sem dúvida a mais importante porque se pode observar nela não somente uma contração drástica da intriga, da história, como no caso das publicações de Dom Quixote em 24 páginas, como também, simultaneamente, um deslocamento de seu gênero. Esse deslocamento consistia em uma mudança da narrativa original, que era constitutivamente apresentada sob a forma de diálogo, de um diálogo entre Dom Quixote e Sancho, e deles com muitos outros personagens, para versões reduzidas que suprimem o diálogo substituindo-o por uma narração de voz única, contínua, a do narrador. Apaga-se, assim, a dimensão dialógica da narrativa que caracterizava o fio condutor das aventuras ou desventuras do herói. Isso não se deu apenas com Dom Quixote. Os romances do escritor inglês Samuel Richardson, como Pamela (1740) e Clarissa (1748), também foram lidos por muitos leitores em uma forma concisa, condensada, que suprimia, nestes casos, a estrutura epistolar do texto original, para substituí-la por uma narração contínua e impessoal assumida por um único narrador que conta uma história.

A terceira classe dessa tipologia refere-se mais propriamente a um dos aspectos que você fez menção, na pergunta. Trata-se da adaptação como forma de adequação de um texto a um público diferente, tal como o público infantil ou juvenil. Dom Quixote, mais uma vez, nos fornece um bom exemplo. Em publicações adaptadas desta obra, na Espanha, no século XIX e XX, observei haver uma forte relação entre a edição condensada e o uso escolar do texto. Isso se inicia a partir da segunda metade do século XIX, em 1856, quando foi publicada uma edição de Dom Quixote por Fernando de Castro y Pajares, cujo título era "El Quixote de los niños e para el pueblo abreviado por un entusiasta de su autor Miguel de Cervantes Saavedra". Esta edição "abreviada" foi publicada em um período em que se entendeu que esta obra poderia desempenhar um papel instrutivo, institucional e útil para as escolas, que se poderia e mesmo se deveria utilizar no ensino primário. A partir dessa primeira vinculação entre uma edição específica "abreviada" de uma obra e o seu uso escolar, se pode observar que se multiplicam, na segunda metade do século XIX na Espanha, essas adaptações destinadas às escolas primárias, tanto religiosas, quanto seculares. Em seus títulos, há sempre a menção de que são obras com destinação escolar. Em 1905, foi publicada uma edição infantil "abreviada" do Quixote, dessa vez não necessariamente destinada para uso escolar, cuja leitura previa-se ser realizada em outros espaços, sem finalidade didática, direta e institucional, e provavelmente para o tempo de lazer. A história das adaptações condensadas de Dom Quixote, destinadas ao público infantil e juvenil, não termina aqui. No começo do século XX, também em 1905, é lançada uma nova edição "abreviada" dessa obra para o público infantil, produzida por Eduardo Vincenti, intitulada "Miguel de Cervantes, El ingenioso Hidalgo Don Quijote de la Mancha. El Libro de las Escuelas. Reducción de la obra inmortal de Cervantes". Seu autor afirmara 
na ocasião do lançamento dessa edição que "se a Bíblia era o livro da Igreja, o Quixote deveria ser o livro das Escolas". Essa nova edição é lançada quando se definem um conjunto de leis regulatórias do ensino primário, entre elas a que recomendava que se deveria incluir, entre os textos para exercícios de leitura, o Quixote adaptado. A partir de 1912, a leitura da obra de Cervantes, em sua versão escolar, torna-se obrigatória. Isso foi regulado com um grau de detalhamento tal que, em 1920, se determinou a todas as escolas do território espanhol a leitura diária e compulsória, de trechos da obra. Todos os dias os professores deveriam, nos 15 primeiros minutos iniciais das aulas, ler um fragmento da obra e explicar a seus alunos de maneira adequada a significação do que foi lido, assim como sua importância ${ }^{4}$. Como se pode constatar, estamos diante de um contexto no qual a adaptação "abreviada" desta obra vincula-se diretamente com o que se acreditava dever ser um material adequado ao ensino primário, em especial da língua e da cultura nacional.

No caso do Brasil, embora eu não seja especialista neste tema das adaptações condensadas e de seus usos em contexto escolar no cenário brasileiro, me parece que encontramos se não a mesma relação ao menos algo aproximado a isso. Um exemplo, e que me chamou muito a atenção, é a edição de 1936 de "Dom Quixote das crianças" de Monteiro Lobato. Este é um texto muito interessante. Embora eu saiba das polêmicas relativas à biografia deste autor, de alguns de seus posicionamentos e de seus ecos em sua produção literária - aspectos sobre os quais pretendo voltar daqui a pouco -, gostaria de me deter, ainda que rapidamente, em certas especificidades da versão adaptada por Lobato da narrativa de Cervantes. Neste caso, o que é realmente fascinante é que estamos diante de um tipo de apropriação do romance de Cervantes muito singular. Lobato opera um deslocamento estético ao inserir, no interior de sua narrativa ficcional, a circunstância de leitura de uma edição clássica do Quixote de Cervantes, mas não de qualquer leitura, porque a prática a que ele se refere é aquela da leitura do impresso vertida para o gênero "conto oral" por uma personagem adulta que já tinha lido a referida edição, de modo a tornar o texto mais acessível a sua audiência composta por personagens infantis. É a narrativa da cena deste reconto que, por fim, e de fato, se torna o livro efetivamente produzido, ou seja, a edição adaptada de Monteiro Lobato. O interessante dessa adaptação de Lobato é sua qualidade metaficcional. O que motiva a leitura do texto, ou melhor, a narração oral adaptada do texto de Cervantes pela personagem Dona Benta é a curiosidade da boneca Emília diante de tantos livros da biblioteca do sítio. Entre tantos, a boneca se interessa por um livro, justamente aquele que se encontrava em uma prateleira alta, inacessível, composto de dois volumes "enormíssimos e pesadíssimos", os quais ela imaginou estarem repletos de imagens. Essa edição a que se faz referência na adaptação lobatiana é uma edição clássica portuguesa do Quixote, datada do final do século XIX, conhecida como a edição dos Viscondes, porque traduzida pelos Viscondes de Castilho e de Azevedo, publicada em 1877. Dona Benta é levada a ler em voz alta esta edição portuguesa, clássica, da obra de Cervantes, a pedido de Emília e de seus netos. Não demorou muito para a boneca reclamar de sua dificuldade de compreensão do texto e demonstrar seu consequente desinteresse por aquela leitura. Emília confessou que não entendeu nada do que Dona Benta vinha lendo: "Se o livro inteiro é nessa perfeição de língua, até logo! Vou brincar de esconder com o Quindim. Lança em cabido, adarga antiga, galgo corredor... Não entendo essas viscondadas, não...". Esse foi o mote encontrado pelo autor da adaptação para justificar o abandono da leitura em voz alta daquela edição clássica destinada ao público adulto, em benefício de uma adaptação oral, de uma contação da história realizada pela personagem Dona Benta: "Em vez de ler, vou contar a história com palavras minhas".

4 Cf. Guereña, 2008. 
O interessante dessa adaptação lobatiana é que ela, além de se referir à própria necessidade da adaptação recorrendo ao subterfúgio ficcional de tematizar e justificar a transposição estética de uma leitura-decodificação de um texto em edição impressa clássica para uma leitura-reconto, sob a forma de um relato oral de uma versão adaptada do texto, nos coloca diante da própria interpretação do texto que a personagem do sítio, Dona Benta, faz da obra cervantina e de seu personagem principal, Dom Quixote, ao declarar que

Dom Quixote não é somente o tipo do maníaco, do louco. É o tipo do sonhador, do homem que vê as coisas erradas, ou que não existem. É também o tipo de homem generoso, leal, honesto, que quer o bem da humanidade, que vinga os fracos e inocentes - e acaba sempre levando na cabeça, porque a humanidade, que é ruim inteirada, não compreende certas generosidades.

Esta interpretação expressa por Dona Benta é uma das interpretações tradicionais da obra Dom Quixote, que emerge no século XIX, segundo a qual a obra se torna um livro que se deve ler, segundo uma visão romantizada desse personagem como um cavaleiro bom, defensor do bem, vítima incompreendida do mundo que o cercava. É com essa interpretação que, no final do século XIX, começo do XX, Dom Quixote adquire o status de obra universal, em função desses valores humanísticos, universais, de defesa abnegada do bem e de luta contra todas as injustiças. Esta interpretação é tão consolidada e esta perspectiva universal é tão fundamental a ponto de ao final da adaptação, se negar a possibilidade de que essa perspectiva possa findar e por isso Dom Quixote, como seu representante, não pode morrer. Emília o demonstra, ao não aceitar, nem ficcionalmente, a morte do herói:

Por várias vezes Narizinho tentou contar a Emília a morte do cavaleiro da Mancha. Emília tapava os ouvidos. - Morreu, nada! - dizia ela. - Como morreu, se D. Quixote é imortal? Dona Benta ouvia aquilo e ficava pensativa...

Assim, essa já longa história das várias adaptações de D. Quixote pode nos conduzir a duas conclusões. A primeira é a de que há um paradoxo central no gesto de adaptar que é o da busca de uma fidelidade através das transformações. Em alguns casos isso até pode funcionar, em outros não. É como se houvesse uma plasticidade tal do texto original ao qual se pudesse ser fiel mesmo através das várias formas de adaptação, apropriação, interpretação. Este seria um primeiro critério de apreciação e de avaliação das adaptações, e que vale para as adaptações contemporâneas. A segunda conclusão que podemos depreender dessa longa história das adaptações de texto é esta que está diretamente ligada ao caso da adaptação de Monteiro Lobato, relativa ao debate sobre sua obra e aspectos polêmicos de sua biografia. Essa polêmica nos coloca diante de uma questão fundamental relacionada ao próprio conceito de 'autoria', do que é um 'autor', questão que nos exige considerar sempre que todas as obras, inclusive as adaptações, devem ser sempre localizadas, individualmente, como textos históricos, no seu tempo. Ao dizer isso, não quero justificar o que não se pode justificar, em relação a certos posicionamentos ideológicos de Monteiro Lobato. O que pretendo é reafirmar a importância de se localizar a produção do texto no seu tempo e espaço, inserida em representações coletivas compartilhadas, muitas delas dominantes, o que nos permite localizar, entender, sem com isso justificar, alguns desses posicionamentos. É muito compreensível toda a controvérsia atual em relação à Monteiro Lobato, porque ele compartilhava posicionamentos ideológicos particularmente radicais e que, hoje, são insustentáveis para nós. Cabe-nos, no entanto, a reflexão sobre sua produção literária a partir de uma visão mais ampla - ainda que diante de temas constrangedores e amplamente reiterados, legitimamente reiterados hoje em dia -, quanto ao que podemos fazer com 
as sombras dessa história que são habitadas por valores, julgamentos e ideias que nos são intoleráveis hoje. Evidentemente, há sempre uma tensão entre conhecimento e consagração. É fundamental compreendermos o que fundamenta a consagração de uma obra e de um autor, e com isso considerarmos que não é porque uma obra foi consagrada antes que se lhes deve continuar a atribuir as formas de celebração canônicas de que dispunham até então, em especial quando estamos diante daquelas que trazem e difundem ideologias tão perigosas e distantes de nossos valores. É também fundamental, ao mesmo tempo, conhecer essas obras e autores que existiram, que obtiveram êxito e que têm uma força literária, poética e cômica singulares, cujo conhecimento adequado não apenas nos autoriza a mantê-las, a considerá-las e a lê-las, tendo sempre no horizonte a sua localização no tempo, a sua condição histórica. Essa oposição entre consagração e conhecimento das obras e autores parece muitas vezes ser radical, no entanto, quase sempre ela encontra uma forma de equilíbrio, de um equilíbrio cujo compromisso essencial é aquele com os públicos, com as formas das edições, com o papel desempenhado pela obra na cultura local e linguística do texto.

Portanto, vimos que a partir da abordagem deste tema da 'adaptação' podemos discutir vários aspectos relativos à cultura escrita de uma sociedade. Um desses aspectos é o que define uma obra, o que constitui todas as suas formas, não somente suas formas materiais, mas também suas formas discursivas: Dom Quixote se mantém Dom Quixote mesmo em uma adaptação distante no tempo daquele de sua produção, em 1605, e em outro espaço, também distinto e distante da Espanha? Outro aspecto que esse tema da 'adaptação' suscita é aquele da reflexão difícil, mas necessária, que nos obriga a discutir, a compreender, e a tomar decisões quanto à legitimidade dos sentimentos do presente concernentes a obras e autores com base na relação entre conhecimento e canonização fundados, ambos, na necessária localização das obras, e particularmente das adaptações, no tempo e na cultura.

Luzmara Curcino: Como historiador, o senhor tem se dedicado a tratar do passado da cultura escrita Ocidental, mas desde a publicação de sua entrevista, concedida a Jean Lebrun, em 1997, e publicada no Brasil, em uma edição muito bonita e hoje muito conhecida, com o título "A aventura do livro: do leitor ao navegador"5, o senhor não tem se furtado a discutir as mudanças do presente relativas às formas de escrita e de leitura contemporâneas. Desde essa publicação, há mais de duas décadas, com as novas tecnologias vimos acelerar cada vez mais a digitalização de textos originalmente impressos e aumentar a produção de textos originalmente digitais. Que impactos o senhor tem observado em relação às práticas de leitura e de apropriação dos textos? Temos lido de modo diferente diante dessa exposição mais frequente aos textos que nos chegam pelas telas?

Roger Chartier: Para te responder isso, me parece ser necessário, primeiro, fazer uma dupla distinção. Primeira distinção necessária, e que você já apresenta em sua pergunta, é a diferenciação entre os textos digitalizados, que tiveram ou que ainda têm uma existência impressa, paralelamente a sua atual existência sob a forma digital, e os textos, ou para empregarmos uma designação mais exata, as criações digitais, que não somente não existiram sob a forma impressa, como também não poderiam existir sob esta forma. Quanto a isso, é preciso fazer duas observações. A primeira delas, é a de que o universo do livro digital, ainda hoje, é dominado pela primeira forma, a da digitalização de textos disponibilizados nesse formato tanto pelas editoras como pelas bibliotecas. Neste caso, estamos diante de um esforço comum de duplicação do impresso de modo a garantir sua existência também no mundo digital, ou seja, de plasmar no universo digital as formas, as práticas, as apropriações herdadas do universo impresso. A segunda observação, em relação às criações digitais é a de que,

5 Cf. Chartier, 1999. 
além de serem irredutíveis às formas impressas, elas ainda são totalmente minoritárias, especialmente as mais interessantes, porque neste caso implicam formas de leitura (com ou sem aspas) totalmente diferentes das formas tradicionais. Até agora me parece que há somente dois campos de produção simbólica que têm explorado essa nova possibilidade de produção de obras. De um lado, o campo da narrativa multimídia, como podem exemplificar as produções intituladas electronic literature. São textos multimídia em cuja construção se exploram a sincronia de diferentes gêneros, se misturam vários recursos de escrita, se sobrepõem distintos tipos de imagens, se intercalam uma multiplicidade de sons, tais como se pode exemplificar com algumas produções do repertório hoje no site disponível na internet designado como Electronic Literature Collection ${ }^{6}$. Estamos neste caso de fato diante de uma série de produções simbólicas digitais reunidas, que em sua singularidade não podem ser chamadas indistintamente de "livro", tal como o conhecemos e tal como o designamos. Esse conjunto de produções é algo mais que um livro, é algo distinto de um livro tal como nos foi legado pela tradição. Trata-se de um cruzamento de várias mídias digitais, de vários gêneros discursivos, de várias linguagens. Resulta de uma associação, tornada possível pela manipulação de uma série de aplicativos disponíveis na internet, de técnicas de produção audiovisual e de técnicas de produção de textos verbo-imagéticos. Essa associação inusitada torna permeáveis certos limites outrora conhecidos, estabilizados, compartilhados que eram mobilizados nas produções do campo audiovisual, do campo eletrônico, do campo impresso. Estamos ainda, evidentemente, diante de um conjunto minoritário de produções, de iniciativas ainda marginais, em constituição. Por outro lado, há um campo um pouco menos marginal hoje em dia, como tem mostrado Regina Zilberman \& Marisa Lajolo (2017): o campo da literatura infantil e juvenil. Nele encontram-se criações simbólicas que, segundo as autoras, resultam de um "hibridismo de linguagens" ou "amálgama de linguagens": das escritas, das imagens, dos sons. Essas produções ainda têm como característica a de convocar o leitor como agente criativo ao longo do processo de apropriação dessas produções. É claro que não estamos diante de uma participação totalmente criativa e livre do leitor, porque evidentemente este participa em conformidade com as escolhas possíveis, ou seja, com as possibilidades de manipulação do texto-objeto já previstas por parte dos criadores dessa produção. Contudo, o que importa, neste caso, é o lugar essencialmente distinto que ocupa o leitor desse tipo de criação frente àquele que ocupava em relação ao livro impresso. Este leitor está diante de uma variedade de trajetos, de atalhos, de idas e vindas, de outras possibilidades de fruição estética, propostas em vários momentos da narração.

Essa é, portanto, uma primeira distinção fundamental que hoje é preciso considerarmos frente às mudanças da produção, circulação e apropriação de textos. A conclusão que se pode chegar feita essa primeira distinção é a de que a primeira forma, a do texto digitalizado, que equivale à cópia ou à reprodução do texto impresso, é ainda amplamente dominante nesse universo virtual, embora, tal como exemplificamos, se possa encontrar hoje um conjunto de criações ficcionais, estéticas, literárias que têm se esforçado em incorporar as possibilidades originais do universo digital. Estas iniciativas, ainda minoritárias, têm buscado romper com a lógica do universo impresso, que tende a se impor, por inércia, em certa medida, à lógica do universo virtual, como é o caso particularmente da digitalização e de sua ilusão, muitas vezes, de equivaler a uma reprodução idêntica, que garantiria uma recepção também equivalente àquela do original.

A segunda distinção, e que me parece ser necessária para melhor compreender o que muda e o que não muda no encontro desses dois universos, impresso e digital, é a da forma de leitura implicada por um 'livro', uma 'obra', um texto impresso e aquela frente às telas, que você, Luzmara, a

6 Cf. https://collection.eliterature.org/ 
pouco mencionou. Ler em uma tela não é o mesmo que ler no impresso, isso porque o tipo de texto para a leitura que nos chega pelas telas da atualidade nos expõe a outras formas, qualitativa e quantitativamente distintas daquelas com as quais estávamos mais familiarizados. Somos mais expostos a formas breves, em alguns casos brevíssimas, de textos que circulam nas redes sociais, sob a forma de tuítes, de mensagens, de comentários e de e-mails. Este é o tipo de texto e de leitura mais onipresentes e aos quais somos expostos e convocados a todo momento e em todo lugar. As práticas de leitura requeridas por estas formas fragmentadas e curtas definem-se de maneira bastante diferente daquelas do universo impresso, ainda que as formas breves também sejam, sem dúvida, um conjunto de produções importantes nesse universo. A ubiquidade dessas formas breves que nos chegam pelas telas intensifica maneiras de apropriação dos textos segundo a lógica da descontinuidade, da segmentação e da brevidade. Trata-se de uma prática de leitura que fragmenta, ao mesmo tempo em que é fragmentada. Esse tipo de leitura se afasta daquele que se vinculava com a própria categoria de 'obra'.

A aposta hoje - não sei se esta seria uma resposta para sua pergunta, talvez uma resposta aproximada - é a de saber se esse tipo de leitura, hoje tornada necessária, por muitos desejada e que se prolifera em especial com os textos que nos chegam via redes sociais, se transformará, ou não, no modelo hegemônico, dominante, exclusivo de leitura, ou se as duas formas de ler, aquela do acesso aos textos em sua totalidade, sejam eles impressos ou digitalizados, e esta do acesso a fragmentos, a formas breves, vão se manter em simultâneo, vão conviver paralela e harmoniosamente. Essa leitura 'proliferante' de fragmentos, que hoje predomina nas redes sociais, desafia a outra, a leitura de totalidades, independentemente de sua forma, eletrônica ou impressa, que supõem uma apropriação mais lenta e particularmente consciente da obra como tal, de suas articulações, de sua lógica ${ }^{7}$. Essa diferenciação se nos apresenta como um desafio, porque quando nos referimos à leitura, quando utilizamos essa palavra, é preciso, hoje, concebê-la nesse seu uso em relação a duas realidades muito diferentes: a da leitura de textos totais, de livros ou de obras, quaisquer que sejam suas formas, impressa ou digital; e a leitura frente às telas de smartphones, de tablets, de computadores, de textos parciais, de fragmentos, de unidades breves, cuja extensão, intensão e ritmo podem ser totalmente diferentes da primeira.

Há ainda um complicador a mais nesta dicotomia entre a maneira de leitura a que somos mais frequentemente expostos no universo digital e a maneira de leitura que se empreende no universo impresso em função do tipo de unidade, de forma, que esses universos mais frequentemente nos propõem. Voltando-nos para a primeira distinção de que já falei, é preciso considerar que mesmo as obras digitalizadas, que reproduzem a forma clássica do livro impresso, uma vez acessadas pelas telas, se favorece com isso uma leitura com tendência à segmentação. Não necessariamente se trata da segmentação absoluta, radical e onipresente das redes sociais, mas de uma segmentação que até poderia passar por idêntica à que realizamos quando da leitura da obra sob a forma total do livro impresso. No entanto, apesar dessa impressão, não estamos diante do mesmo processo, nem da mesma lógica de segmentação.

No caso da leitura mediada pela tela dessas unidades ou totalidades, pode se observar a prática que tendencialmente fragmenta o que se lê, segundo a qual não se percebe ou nem mesmo se vê como sendo necessário perceber a obra como tal, como uma totalidade. Isso porque a leitura frente à tela é sempre uma leitura de um fragmento, de um trecho, do trecho que temos diante dos olhos, nesse espaço bem delimitado. Esse fragmento, esse trecho que temos sob os olhos se autonomiza.

7 Cf. a esse respeito Chartier, 2019. 
Embora no livro impresso, também estejamos diante de um fragmento, aquele contido na página lida, a ideia da totalidade do texto fica materialmente expressa nesse objeto, que se apresenta como uma unidade formal e material de um todo, no qual cada trecho se localiza, se organiza, se articula em função dessa totalidade. Mesmo quando o leitor não realiza a leitura da obra em sua totalidade, quando ele a interrompe ou quando ele a consulta em função de seu interesse por uma parte específica, ainda assim essa leitura de um fragmento não prescinde da percepção da obra em sua totalidade. Isso é muito diferente frente à tela.

O tipo de leitura mais em conformidade com o tipo de texto proposto nas redes sociais pressupõe uma forma de acesso mais acelerada, impaciente, fragmentada e que fragmenta, o que afeta a nossa recepção de outros textos, mesmo aqueles mais extensos e semelhantes aos textos do universo impresso, como é o caso dos livros digitalizados. Esse é o caráter complicador do acesso aos textos pelas telas: mesmo a obras digitalizadas, reconhecidas em sua extensão e concebidas em sua totalidade estão suscetíveis à facilidade, à tentação da possibilidade de sua fragmentação, uma fragmentação não dos textos, mas de sua recepção. Disso advém uma conclusão: tem-se falado bastante dos riscos, dos perigos da "morte do livro" concebido como materialidade, no entanto, o que tem ocorrido é algo diferente. O que parece estar em jogo, não é necessária, prioritária e exclusivamente a 'morte do livro', tal como o conhecemos em sua forma impressa, mas sim, e é isso que aqui estamos discutindo, o que está em jogo é a 'morte do livro' como forma discursiva, ou seja, como uma arquitetura textual, como uma totalidade na qual cada elemento desempenha um papel na narração, na argumentação, na demonstração a que ele pertence. A percepção dessa arquitetura textual, dessa totalidade de um texto, de uma obra, de um livro é o que está em jogo, quando o modo de ler frequentemente estimulado pelos demais tipos de texto de acesso privilegiado por essas tecnologias do universo digital é aquele familiarizado ao fragmento. Portanto, a discussão sobre a morte ou desaparecimento do livro deve se deslocar da discussão entre o livro como forma material - e-book ou livro impresso - para uma discussão sobre o livro como forma discursiva, como uma 'obra', como uma totalidade, cujo estatuto se encontra hoje em xeque, na sua recepção, no universo digital.

Luzmara Curcino: Quanto a isso, os professores têm um papel decisivo na garantia da capacidade de reconhecimento dessas diferenças dos textos que nos são apresentados hoje por meio da tela, e da compreensão dessa distinção das formas de ler. As novas gerações têm direito de saber como, em geral, em função da exposição frequente e predominante a certas realidades textuais suas práticas de apropriação dos textos são progressivamente subjetivadas, podendo assim ser mais facilmente suscetíveis de controle.

Roger Chartier: Exatamente. As gerações de leitores, que hoje encontramos em sala de aula, são leitores bastante familiarizados com as redes sociais, com os textos por elas propostos, e que já vêm praticando massivamente uma forma de leitura relativamente mais indiferente à apropriação lenta, atenta, exclusiva e completa de um único texto, em especial daqueles que exigem essa forma de apropriação. Essa geração, hoje nos bancos escolares, é aquela que desde cedo tem tido acesso aos textos a partir de um mesmo suporte, meio em que se encontram obras que merecem ou exigem um outro tipo de leitura, avizinhadas aos fragmentos, aos formatos destinados a leitura imediata, rápida, provenientes das redes sociais. Essa vizinhança pode reforçar o apagamento dessas distinções dos textos e com elas das distinções necessárias de sua forma de apropriação, fomentando com isso a lógica da recepção por fragmentos, da leitura fragmentação. 
Luzmara Curcino: Além dessa mudança relativa aos modos de circulação dos textos e de sua leitura com tendência à fragmentação quando ambientados nesse universo digital, uma outra bastante sensível é a de que mais gente passou a travar contato com o texto escrito, graças à expansão do acesso à internet e a aplicativos de comunicação e de produção e circulação de informação, como o WhatsApp, de grande sucesso no Brasil. Esse meio, aliás, desempenhou importante papel na propaganda política nas últimas eleições brasileiras. Um amplo público - dos mais jovens aos mais maduros, mas especialmente estes últimos - compôs um segmento de "novos leitores" que, embora soubessem ler e lessem eventualmente, eram até então, em geral, pouco expostos a textos escritos. Este público tradicionalmente se informava pelos noticiários e se entretinha com as novelas da TV. De repente, de posse de celulares e desses aplicativos gratuitos, foram bombardeados por textos de grande apelo moral e religioso, formulados com malabarismos retórico-argumentativos convincentes, em geral em linguagem acessível e popular, em reiteradas publicações que exploravam os principais medos urbanos das camadas pauperizadas, como a violência, a dissolução de vínculos familiares, a corrupção e tantos outros. Com essas estratégias se difundiram muitas mentiras políticas, que afetaram decisivamente a opinião desse público e as eleições no país. Tamanha foi a segmentação dessa propaganda junto a esse público, e tamanho foi o impacto sobre eles, que até se cunhou um termo pejorativo e misógino para designá-los em sua condição de 'novos leitores', cuja opinião foi formada com base nisso que liam, como 'a tia do WhatsApp'. Assim, por um lado, a baixa escolaridade e a pouca familiaridade com essas estratégias de escrita e com esses gêneros digitais foram decisivos no sucesso obtido por essas produções escritas. Por outro lado, a familiaridade dos jovens, nativos digitais, que desde cedo têm sido incitados "aos usos impacientes", tal como o senhor tem afirmado ${ }^{8}$ fez com que se disseminasse esse modo de ler mais aligeirado, mais panorâmico, mais distraído ${ }^{9}$, e por isso mais frágil criticamente e mais suscetível à crença diante das falsificações que se multiplicaram por meio das redes sociais, e que sistematicamente, como o senhor mesmo afirmou em seu belo texto "Verdade e prova: retórica, literatura, memória e história"10, adulteram o passado e o presente. Dadas essas observações, o senhor acredita que, na atualidade, nossa sociedade está mais suscetível a esse risco da apropriação em massa, desavisada e frágil, de falsificações e mentiras convincentes graças às novas técnicas de produção e circulação digitais de textos?

Roger Chartier: Com sua pergunta, adentramos na selva das ansiedades de nosso tempo. Essa é, sem dúvida, uma questão fundamental, que nos atinge como sociedade e que devemos responder como sociedade. Testemunhamos, hoje, a proliferação da produção de falsificações do presente e do passado e, o que é mais sério, da crença nessas falsificações, de seu reconhecimento como verdade. Parece-me que podemos pensar três razões que explicam essa proliferação.

A primeira razão, e que você mencionou a pouco, é aquela relativa à transformação das práticas de leitura dos textos que circulam virtualmente e que são caracterizadas pela aceleração. Este não é um diagnóstico específico em relação à leitura. Este é na verdade um dos indícios e um dos resultados da aceleração da lógica temporal que caracteriza as sociedades Modernas, tal como a descreve o sociólogo alemão Harmut Rosa (2005). Uma série de pesquisas sociológicas demonstram essa aceleração associada aos "usos impacientes" dos textos, mas não apenas em relação a eles, como também aos filmes ou à música. Esses "usos impacientes" têm como uma de suas consequências uma relação menos preocupada ou comprometida com a avaliação dos conteúdos lidos, vistos ou ouvidos e, portanto, como você disse, responsáveis por um consumo mais distraído. Não sem razão, a reflexão sobre a veracidade

8 Cf. Chartier, 2020, p. 108.

9 Cf. Curcino 2011.

10 Cf. Chartier, 2021, p. 19 e 38. 
do que tem sido consumido não aparece nas respostas quando se entrevistam jovens leitores ou leitores que utilizam redes sociais. Nunca, ou quase nunca, é mencionado nessas respostas a importância de se questionar ou de se refletir sobre a veracidade do que thes chega como informação, como verdade. É como se essa aceleração da vida moderna, e com ela da leitura dos textos que circulam virtualmente, evitasse, justificasse ou produzisse essa ausência da necessária distância crítica que se deve ter em relação ao que se lê, se vê ou ouve. Uma primeira razão para a ampla e poderosa proliferação das falsificações, atualmente, parece-me estar vinculada com essa transformação das práticas de leitura, adaptadas ao ritmo de outras práticas cotidianas, imediatas e universalizadas de uso dos diversos aparelhos e aplicativos de comunicação digital. Se por um lado não há uma preocupação explícita e consciente, de boa parte dos leitores, com a veracidade do conteúdo do que circula via redes sociais, por outro, há incontestavelmente uma produção sistemática e consciente na produção e na proliferação dessas falsificações que circulam sob a forma de texto. Aqui me parece que estamos diante de um deslocamento fundamental, que concerne não somente aos leitores mais jovens, mas a todos os leitores. Esse deslocamento diz respeito à mudança de critérios mobilizados para o estabelecimento da verdade. Se antes isso dependia do exame do enunciado, daquilo que se leria, e que estaria submetido, consciente ou inconscientemente, meticulosa ou mais rapidamente, a critérios de comparação, de avaliação, de crítica, necessários para o estabelecimento da condição de verdade do que é enunciado, afirmado, informado, hoje em dia, a confiança na veracidade do que é dito é oriunda de um modo peculiar de circulação desse dizer e de sua proliferação por meio das redes sociais.

Essa é, para mim, a segunda razão, muito poderosa, responsável pela multiplicação das produções e da circulação de falsificações. Esse veículo de enunciação responde por uma outra lógica de autenticação, de validação e de aceitação como verdade daquilo que é enunciado por meio dele, e que depende diretamente da confiança entre os participantes de um mesmo grupo ou de uma mesma rede de relacionamento. Esse deslocamento é absolutamente fundamental porque no lugar do exame crítico do enunciado, se aposta na confiança plena, absoluta e imediata que em geral depositamos naqueles que conhecemos, com os quais nos relacionamos, com os quais nos identificamos e com quem formamos redes sociais, e isso graças a essa forma de operar desse veículo de enunciação. Diante de uma afirmação, de uma informação em circulação nesse meio, ela pode mais facilmente ser assumida como verdade em função da confiança que se deposita, consciente ou inconscientemente, no que foi enunciado, em função de sua enunciação por esse meio, nessa rede da qual os participantes se tornam o fator de certificação, de credibilidade do que nela é enunciado.

A terceira razão diz respeito ao poder e à força política, empresarial, comercial e técnica, adquiridos nos últimos tempos pelas plataformas de comunicação digital, tal como a que você mencionou. Em relação a esse tema, recomendo assistirem a uma série documental produzida pela televisão francesa, intitulada "La fabrique du mensonge"11, dedicada a decriptar diversos usos das tecnologias digitais, em particular aqueles sob encomenda para finalidades político-eleitorais, tal como o uso a que você referiu, Luzmara, na última eleição presidencial no Brasil. O que chama a atenção é a vinculação estratégica, nesses dispositivos predispostos à circulação de falsificações, desses dois aspectos a que me referi: da credulidade e da confiança nos sujeitos exploradas pela arquitetura desse meio digital de enunciação; e desse novo padrão, desse novo modelo de leitura "impaciente". Você citou o exemplo do WhatsApp. Sem dúvida, ele é uma dessas tecnologias baseadas na lógica de construção de redes sociais, e que se prestaram recentemente como meio muito propício para essa difusão de falsificações e de seus usos com diferentes finalidades.

11 "A fábrica de mentiras: fakenews por encomenda". Documentário, difundido como série televisiva pelo canal France Télévision, em 2021, com direção de Arnaud Lievin e Elsa Guiol. 
Este aplicativo, o WhatsApp, se mostrou muito eficaz nesse papel por apresentar duas características. A primeira é seu mecanismo dinâmico na difusão da falsificação, dado que o WhatsApp funciona sobre a base de grupos de discussão, de até 250 pessoas, que podem produzir, gerar, compor outros grupos de discussão. Com isso, estamos diante de um dispositivo muito adequado à multiplicação da transmissão das ideias falsas, das mentiras, de maneira muito mais rápida e poderosa do que aquela das redes sociais mais clássicas, com limites técnicos de ação, com fronteiras estabelecidas. No caso do WhatsApp, há uma proliferação quase biológica da circulação das falsificações, semelhante ao da transmissão de um vírus, porque a estratégia de base da construção desse aplicativo foi a de habilitar cada usuário a produzir novos grupos de discussão e a participar de vários grupos existentes, contribuindo com a multiplicação das formas de contato dos usuários em diferentes grupos e com eles da circulação de falsificações de maneira mais rápida, difusa, individual, não institucional e mais difícil de identificação de sua origem.

A segunda característica do WhatsApp é o de ser uma plataforma digital, cuja empresa não assume o controle dos conteúdos que circulam neste meio, logo, não assume a responsabilidade por eles. Apenas diante de grandes escândalos, empresas como o WhatsApp criaram alguns "freios" tecnológicos para inibir até certo ponto, por exemplo, os disparos em massa, que antes eram possíveis e que foram amplamente utilizados com o auxílio de programas, máquinas e operadores que, no lugar dos usuários individuais, distribuíam esses conteúdos, que eram a partir de então replicados pelos próprios membros dos grupos de maneira reticular, simultânea e difusa. Excetuando essas circunstâncias, as empresas responsáveis por esses aplicativos sustentam sua 'neutralidade', sua função meramente técnica como fornecedoras de um aplicativo, de um meio, de um recurso que, portanto, não tem consciência do conteúdo que transmite, logo, não tem responsabilidade sobre ele. O sucesso do WhatsApp foi favorecido pelo aumento do acesso aos aparelhos celulares e pela ausência de controle jurídico do que circulava por este meio, cuja empresa, assim como as outras responsáveis por outros aplicativos e plataformas também não têm, nem advogam o controle sobre o conteúdo, resguardando-se, portanto, nisso, em não se poder estabelecer uma responsabilidade da empresa quanto ao conteúdo transmitido pelos recursos técnicos que ela disponibilizava, como o caso do WhatsApp.

Não se pode esquecer outro aspecto crucial, recentemente descortinado, desse mundo digital: o da venda, por parte dessas companhias, de dados pessoais e de números de telefone de seus usuários para as empresas de marketing digital. Esse procedimento foi responsável pela constituição de um enorme banco de dados, de conexão com números de telefones, e pela possibilidade de enviar, em uma escala absolutamente desconhecida, industrial e automatizada, de notícias falsas, de mentiras, intercambiáveis tecnologicamente por uma série de outras plataformas. Isso viabilizou o comércio desses bancos de dados das empresas que trabalham no marketing do mercado digital em benefício de projetos políticos que se valeram dessa possibilidade de enviar mensagens a milhares de usuários, mensagens falsas, mentiras e difamações.

Se considerarmos esses três elementos, o cultural, relativo a essa transformação da prática de leitura e seus "usos impacientes" com a expansão dos textos mediados pelas telas, o tecnológico, relativo aos recursos que permitem a multiplicação e a ampla difusão de textos de forma direcionada, e o psicológico, relativo à crença no que se enuncia, fundamentada dessa vez não necessariamente no conteúdo transmitido, mas antes no meio de transmissão que explora as relações de confiança interindividuais e intragrupos, o que vemos é que estamos frente a uma situação um pouco semeIhante àquela expressa no famoso ensaio de Walter Benjamin sobre a reprodutibilidade técnica da 
arte $^{12}$, especialmente da imagem. Segundo o autor, as tecnologias em si mesmo não são perigosas. Elas são um mero instrumento. Integradas, no entanto, em um paradigma cultural específico e submetidas a certos apelos psicológicos, essas tecnologias podem se colocar a serviço da manipulação política, o que infelizmente temos testemunhado. O mais importante, a meu ver, ao estudarmos esses fenômenos, é nunca separar a análise da disponibilidade tecnológica, da disposição psicológica e da transformação das práticas culturais.

Luzmara Curcino: A observação que o senhor nos apresenta relativa à mudança dos critérios de credibilidade do que é enunciado, que migra da avaliação consequente da própria mensagem para o veículo, ou melhor, para a forma como ele simula, reproduz e restitui certas relações de confiabilidade de mensagens que circulam no interior de grupos cujos membros se conhecem e cujos membros difundem, atuando assim como seus fiadores, me fez lembrar de um episódio que presenciei há uma década, em 2011, quando Fernando Haddad ainda era ministro da educação. Ouvi de uma senhora, em um salão de beleza, a notícia de que havia um projeto em curso de distribuição de um "kit gay" destinado a alunos nas creches e escolas, e que tinha por objetivo induzir as crianças a mudarem de gênero ${ }^{13}$. Tamanho foi meu susto ao ouvir isso, e de forma tão assertiva, em uma circunstância tão banal, que interpelei a senhora sobre a origem desse boato, ao que ela refutou afirmando não se tratar de um boato, já que ela tinha lido isso em um texto de jornal. Eu então perguntei em que jornal. Ela respondeu que leu no jornal da igreja evangélica que ela frequentava. Eu insisti criticando a veracidade da informação atribuindo a algum equívoco da mídia em questão. Ela mais uma vez afirmou ser verdade, dessa vez afirmando que o jornal era distribuído para milhares de leitores. Assim, vemos o quanto o que é enunciado adquire valor de verdade não simplesmente em função do que é dito, por mais absurdo que o seja. Seu valor de verdade se relaciona com o modo como o enunciado é materializado sob uma certa forma de registro, como a escrita, em um dado gênero editorial, como notícia de jornal, em um meio institucional, como mídia de uma igreja, e ainda porque se dirige a um público amplo. Esses critérios mobilizados por essa senhora para validar aquela informação que recebeu e justificar sua crença no que foi dito demonstram o papel simbólico do meio, do veículo, como forma de tornar fiável e crível, mesmo informações muito improváveis como aquela.

Roger Chartier: Este seu exemplo demonstra como essa senhora, em certa medida, estava inscrita em um outro paradigma da interpretação, aquele de um modelo antigo relativo à ideia de que, porque está impresso, é verdadeiro. No século XVII, a expressão in-print, em inglês, significava que se estava diante de algo verdadeiro, de um dizer sério. A diferença do que ela disse reside no fato de que hoje é verdadeiro não apenas porque foi impresso, mas especialmente porque está na rede, rede da qual sou um participante, e os demais participantes, como eu, não são mentirosos e transmitem informações nas quais se pode/deve crer. Esse é exemplo claro de como se dá esse deslocamento da fiabilidade, que passa do critério da análise crítica do enunciado para a credibilidade outorgada aos meios, nos quais se encontram o enunciado. Estamos, portanto, frente a essa forma distinta de manipulação que pode encontrar nos recursos tecnológicos absolutamente novos da atualidade um forte aliado, desde que haja condições culturais e psicológicas propícias ao fomento da crença dessas manipulações, tais como a exploração da confiança no que circula por um veículo, em função da

12 Benjamin, 2000 .

13 Trata-se de proposta recomendada pela UNESCO, formulada pela Comissão de Direitos Humanos e Minorias da Câmara dos Deputados e apresentada ao Ministério da Educação relativa à formulação de material didático, vídeo e cartilha, com orientações para professores, com vistas ao combate à homofobia. Embora o material não tenha sido sequer submetido à avaliação e aprovação do MEC, muito menos distribuído nas escolas, o boato difundido pelo então deputado Jair Bolsonaro, e hoje presidente do Brasil, circulou amplamente em diversos meios, sobretudo nas instituições religiosas. 
confiança prévia do que enunciam seus participantes, que são os fiadores do que ali é enunciado. Diante desse cenário de afastamento de uma prática de leitura crítica, incrédula, desconfiada, é preciso que nos façamos atentos e que observemos criticamente o presente, não nos limitando à simples denúncia da tecnologia, em si mesma, mas nos ocupando da produção de um diagnóstico da condição social e histórica do uso dessa tecnologia que a torna, ou não, um meio de destruição da verdade.

Luzmara Curcino: Entre os aspectos socioculturais e históricos que a onipresença dessas tecnologias hoje nos convocam a refletir, é preciso considerar o fato de que as novas gerações têm travado contato, cada vez mais precoce e cada vez mais frequente, com textos do universo digital. No que diz respeito ao público leitor infantil, junto ao qual textos sob a forma digital gozam de relativo sucesso, sendo recebidos pela tela de celulares e atuado como um dos brinquedos prediletos na captura da atenção dos pequenos, é possível afirmar que esses textos afetam de alguma maneira a relação que essa geração vai estabelecer com os textos do universo impresso? Essa geração lerá como as anteriores? Já dispomos de elementos para algumas predições nesse sentido?

Roger Chartier: Infelizmente não tenho nem a competência nem os dados para arriscar uma predição. O que podemos adiantar a esse respeito, retomando e aprofundando um pouco a resposta que dei a uma pergunta anterior nessa nossa conversa, é a importância de pensarmos que efeito esta nova cultura da leitura pode produzir em relação às práticas de leitura dessa geração, e isso no sentido amplo da palavra 'leitura', entendida como forma de apropriação não apenas de textos verbais, sob a forma impressa, mas como apropriação desses textos resultantes de uma mistura de gêneros, linguagens e mídias. Podemos considerar que estamos diante de um novo tipo de relação cultural com as produções em circulação hoje, o que pode transformar profundamente as expectativas ou as interpretações dos leitores. O que podemos constatar até o momento é que as predições possíveis quanto as mudanças na forma de apropriação das produções no mundo digital não se limitam às crianças.

Uma pesquisa recente do Ministério da Cultura Francesa, dedicada ao levantamento de dados relativos às práticas culturais dos franceses, e que é realizada, há várias décadas, a cada 4 ou 5 anos, como uma espécie de censo cultural, mostrou que, em 2018, de cada 6 franceses, 1 declarou que todas as suas práticas culturais são digitais. Isso significa que 15\% dos franceses não fizeram referência a outras práticas culturais, como a ida a um concerto musical, a uma peça teatral, a leitura de um livro impresso. Eles fazem parte, portanto, de um mundo cultural inteiramente digital, e não estamos nos referindo a crianças de 5 anos. Estamos diante de gente de todos as idades, majoritariamente adolescentes ou jovens adultos. De qualquer modo, este me parece ser um indício importante e que devemos acompanhar com interesse, porque ele revela que a prática cultural desse grupo, relativa à apropriação de jogos virtuais, de vídeos online e de leitura eletrônica de textos, exclui outras formas do consumo cultural. Essa já é, portanto, uma realidade no presente atual, ainda que somente para uma minoria da população. Este pode vir a ser o futuro das gerações mais jovens: o de reforçar o contingente desses $15 \%$ de franceses cujo consumo cultural é inteiramente digital. E neste caso, é preciso considerar a ambivalência, a que nos referimos, em relação ao modo de avaliar esse consumo, já que os objetos digitais que são acessados hoje em dia tanto podem ser livros antes impressos e agora digitalizados, como podem ser criações simbólicas digitais inovadoras, ou ainda a circulação pelas redes sociais virtuais diversas.

Nessa mesma pesquisa do Ministério da Cultura francês, há outro dado que comprova a complexidade dessas predições e os indícios que nos permitem pressupor algumas. Tal como ocorre na pesquisa semelhante que vocês realizam aqui no Brasil, a "Retratos de Leitura no Brasil", há uma 
pergunta clássica desse tipo de questionário, uma pergunta inicial e que atua como parâmetro para se decidir que entrevistados terão seus dados considerados no levantamento. Na pesquisa francesa, só se consideram os dados daqueles que declararem ter lido pelo menos um livro nos 12 últimos meses anteriores à consulta ${ }^{14}$. A resposta, no caso francês, em 2018, era a de que $73 \%$ dos entrevistados, de um total de 9.200 consultas, disseram ter lido pelo menos 1 livro no ano anterior. Quando se distribui essa porcentagem por gerações se observa que, para os entrevistados nascidos entre 1995 e 2004, entre 14 e 25 anos, a porcentagem que equivale a essa informação é de 58\%. Se confrontada com a porcentagem global de $73 \%$ na média geral de todos os grupos, se constata já haver entre os jovens franceses dessa faixa etária um afastamento da leitura de livros impressos, de modo que não é preciso esperar o crescimento das crianças de hoje para mensurar o impacto do acesso, da oferta e do uso cultural das produções do universo virtual. Ao confrontarmos esses dados, já se pode antever que, mais do que os jovens de hoje, cujas práticas intelectuais, culturais e cotidianas já se encontram fortemente relacionadas ao digital, as crianças que têm sido expostas mais precocemente e mais frequentemente às práticas do mundo virtual contribuirão para acentuar a distância entre esses dados estatísticos.

Frente a esta trajetória já desenhada pelos que hoje vivem no mundo totalmente digital, seja para fins culturais, seja em função do trabalho, seja para realizar suas compras, o que, aliás, se acentuou drasticamente neste período de pandemia e de necessário isolamento social, não se pode ignorar que estamos vivenciando o tempo das telas. É por meio delas que tem se realizado comunicações formais, informais, compras, assim como a leitura de textos. Este momento - que tem se estendido muito, já que estamos há um ano e alguns meses nesta situação - contribuirá, sem dúvida, para uma mudança das práticas, de modo a diminuir nossa eventual resistência às telas, de modo a nos acostumar a sua presença mais frequente em nossas atividades e, com isso contribuir para a provável diminuição dos números relativos à leitura de livros impressos, o que já se iniciou para esta geração, para os adolescentes e jovens adultos de hoje.

Nestas considerações que fiz, busquei apresentar alguns elementos de modo a melhor situar o contexto em relação a sua questão e à apreensão nela contida. Não há predição exata. O que há de certo em relação ao futuro é que, se não quisermos nem concordarmos com essa transformação digital de todas as nossas práticas culturais, devemos, como cidadãos ou como professores, como compradores e leitores de livros ou como seus produtores, atuar de maneira mais consciente na apropriação dos objetos culturais que se tornaram produtos digitais, estabelecendo com eles uma relação diferente, considerando-os tanto no que diz respeito a sua injunção à aceleração do consumo e à fragmentação dos objetos, quanto no que diz respeito à exploração de suas criações simbólicas atrativas, interessantes, fascinantes até. É crucial, para nós como sociedade, que a relação com as produções culturais digitais não seja a única relação que as gerações futuras estabelecerão com o mundo simbólico.

O único meio de evitar isso é assumirmos a defesa irrestrita e a proteção das instituições que representam essa cultura tradicional e impressa. Assim, mais do que empreender uma crítica com vistas a evitar ou impedir as mudanças geradas pela emergência e expansão da tecnologia digital - até porque essa seria uma luta vã, já que não há retrocesso possível -, é preciso lutar pela manutenção da pluralidade e da diversidade dos meios, dos objetos, dos modos de ler e das práticas culturais de ambos os universos, impresso e digital. Este é o caminho que acredito ser o mais adequado e viável

14 No caso da "Retratos da Leitura no Brasil", consideram-se os dados daqueles que disseram ter lido pelo menos um livro, inteiro ou em partes, nos últimos três meses. 
para seguirmos, explorando as potencialidades de nossa situação atual, na qual convivemos com a pluralidade das formas de inscrição das imagens, do som e da escrita, com a pluralidade dos meios de seu acesso, com a pluralidade enfim das formas de nos apropriarmos dessas linguagens e dos textos ou produções em que elas se encontram manifestas.

Luzmara Curcino: Para desfrutarmos dos benefícios dessa pluralidade e das potencialidades dessas novas tecnologias digitais de produção e circulação de textos a que o senhor se referiu, um dos entraves decisivos para isso, hoje, é o de garantir que todos possam indistintamente ter acesso qualificado e crítico a essas tecnologias. Em função da pandemia, com a necessidade de fechamento dos espaços de sociabilidade da leitura e de acesso aos livros, como as bibliotecas, as livrarias, as feiras de livros, assim como com a abrupta adaptação das aulas para o ambiente virtual e remoto, nos vimos alijados desses espaços e daqueles das escolas e universidades. Esse cenário escancarou, entre nós no Brasil, o fosso social e cultural profundo que nos divide. Hoje somente uma minoria dos alunos das camadas populares no país, especialmente da Educação Básica, têm acesso às aulas tornadas remotas, de maneira apressada e improvisada, e aos materiais digitais dessas aulas. São várias as razões para isso. Uma delas me parece ser uma forma de afeto que nós nutrimos pelo espaço de encontro que a escola representa, em uma sociedade de indivíduos separados, cada vez mais ilhados e mais solitários. Quanto ao fosso social e cultural, ele se amplia, sobretudo se considerarmos que na formação dos leitores iniciantes, em especial daqueles provenientes das camadas populares, a ausência nessas aulas virtuais, por falta dos meios tecnológicos para isso, e a impossibilidade de ter acesso ao livro físico, cujo encontro só se dava na escola, na sala com o professor ou nas estantes e no espaço da biblioteca escolar, podem ter um impacto muito grande na formação, como leitores, dessas crianças.

Roger Chartier: Com certeza. Sua observação nos remete ao que você disse no início deste diálogo com palavras emocionantes e verdadeiras. A pandemia mundial não apenas tornou mais visível, como também aprofundou as desigualdades sociais. Nem todos, em nossas sociedades, correm os mesmos riscos sanitários, como você disse, ou são impactados da mesma forma e diretamente com o aumento da desigualdade na distribuição dos recursos econômicos. Nem todos puderam adaptar suas condições de vida e de trabalho, de modo a se protegerem, podendo se valer de recursos digitais, de acesso a material digitalizado e de ensino remoto emergencial. Esta é uma realidade incontornável, a da desigualdade social e a de sua intensificação no contexto da pandemia. Por essa razão, gostaria de reiterar a importância que desempenham, na sociedade, certas instituições. Ainda que elas não possam apagar as desigualdades sociais, elas são fundamentais porque podem limitar seus efeitos.

Fazem parte dessas instituições, a escola, a biblioteca escolar, a biblioteca pública, e porque não as livrarias e feiras de livros. Estas são instituições que, ao desaparecerem ou serem substituídas por uma interlocução digital, com o seu material digitalizado, com os encontros tornados remotos, têm essa sua capacidade de limitar as desigualdades muito enfraquecida. No que diz respeito às escolas e universidades, sem dúvida alguma, as aulas são um elemento essencial, talvez o mais essencial, mas você tem razão de lembrar e de mencionar a importância das bibliotecas dessas instituições na formação geral dos alunos e em sua formação como leitores. A importância das bibliotecas se pode medir por meio de dados bastante concretos. Vou dar um exemplo, utilizando aqueles que foram obtidos pela pesquisa "Retratos da leitura no Brasil". Uma primeira constatação interessante é a de que entre os anos de 2011 e 2015, o número de leitores - entendidos aqui conforme os critérios de seleção desta pesquisa, como aqueles que leram pelo menos 1 livro, parcial ou completamente, nos últimos 3 meses-, 
aumentou, passando de 50\% em 2011 para 56\% em 2015. O Brasil é um país muito grande, de modo que esse aumento de $6 \%$ pode parecer um aumento pequeno, mas esse número representa 6 milhões de novos leitores, o que de modo algum é um número negligenciável. O que explica esse crescimento? Sem dúvida, uma melhoria no número de anos de escolarização, uma diminuição nos índices de evasão escolar, uma melhoria na qualidade de formação dos docentes. Uma outra razão decisiva para esse crescimento foi a formulação e implementação, ao longo desses anos, de uma política pública de incentivo à leitura e de acesso ao livro. Entre outras medidas, criaram-se e modernizaram-se bibliotecas públicas. Não sem razão, nessa mesma pesquisa, 50\% dos leitores consultados afirmaram ser a biblioteca o espaço e meio principal de acesso aos livros e de realização da leitura. Isso demonstra, irrefutavelmente, a relação direta, imediata e determinante, entre políticas públicas de promoção da leitura - não apenas baseadas em propaganda, mas na criação e na modernização de bibliotecas - e crescimento do número de leitores.

Esta mesma pesquisa, baseada nos mesmos critérios, foi realizada em relação aos anos de 2015 a 2019, e publicada em 2020. Nela fica evidente que estamos diante de uma tendência inversa. A porcentagem dos leitores passou de 56\%, em 2015, para 52\% em 2019. Novamente, como o Brasil é um país grande, essa queda no percentual significa uma perda de 4,6 milhões leitores. Essa perda é o retrato sem retoques do desmantelamento das políticas públicas de promoção da leitura no país, em especial daquelas relativas ao esforço de ampliação da rede de bibliotecas públicas em todo o território nacional. Essa é uma lição muito potente quanto à demonstração da importância de políticas públicas qualificadas. Com ela se observa o quanto os fenômenos culturais estão vinculados a decisões políticas. Esses dados demonstram, portanto, como você dizia, o papel decisivo desses espaços de leitura que extrapolam a convivência privada, desses espaços de leitura que promovem uma convivência pública, que permitem e produzem trocas de experiências coletivas de leitura. Nesse espaço de sociabilidade se reduzem as desigualdades sociais, uma vez que cada um se encontra ali na mesma situação institucional e cultural, e no mesmo tempo, simultaneamente. A biblioteca é um lugar de aprendizagem da cultura escrita e impressa, um lugar onde se pode aprender acerca dos perigos de algumas publicações e da utilidade fundamental de outras. De todo modo, este é um lugar de circulação da palavra em sua forma escrita. Esta circulação da palavra é um elemento central da vida pública em uma sociedade democrática, e a biblioteca é um dos espaços públicos onde se pode exercer essa liberdade cidadã.

Além disso, ler não é somente uma experiência intelectual, é também uma experiência emocional, uma experiência que implica afetos, que implica uma relação com os outros, e isso se experimenta quando existe um lugar de convivência ou de trocas, o que não necessariamente é experimentado da mesma maneira quando estamos isolados diante das telas. Nesse sentido, é verdade que a comunicação digital permitiu, nesses tempos de pandemia, uma forma de acesso a aulas, de participação em congressos, de conversação com os amigos. Esta talvez seja a maior diferença entre esta pandemia e todas as pestes ou pandemias do passado. Graças às tecnologias do mundo digital foi possível manter algo aproximado ao que era o ensino na escola, ao que eram as aulas nas salas, ao que eram os diálogos entre colegas de turma. Ao mesmo tempo, o uso dessas tecnologias e a realidade do mundo digital nos fizeram experimentar um tipo de frustração, uma espécie de carência, uma sensação de falta. O que nos faz sentir essa ausência, o que nos falta é, sem dúvida, a experiência emocional do encontro, de estar no mesmo lugar, ao mesmo tempo com os outros. Até mesmo as crianças mais familiarizadas com o mundo digital vivenciam este sentimento de falta, diante dessas formas digitais de compensação do contato que são, ao mesmo tempo, uma espécie de mutilação, 
de falta, de ausência, que se traduz em queixas relativas ao não retorno das aulas. Experenciamos, assim, um mundo ao avesso, já que antes se dizia que as crianças não queriam ir para a escola para poder brincar com os amigos e, hoje, não poder ir para escola se tornou uma queixa quase universal dos alunos. Não compartilhar fisicamente o espaço da escola significa se distanciar dos outros, assim como dos objetos que constituem este espaço, entre eles o livro, ausente na maioria das residências desses alunos.

Como vocês sabem, me agrada muito a ambivalência da palavra "cuerpo", tal como era empregada em castelhano, nos séculos XVI e XVII. Essa palavra tanto era empregada em referência ao corpo físico dos indivíduos como também aos exemplares de uma edição, aos volumes de uma obra. Residia aí a ideia de que também a materialidade da escrita equivalia a um corpo, seu sentido à alma. As bibliotecas seriam, assim, o lugar de encontro dos corpos dos leitores com esse corpo dos livros. Dessa maneira, esse lugar das bibliotecas, das feiras de livros, das livrarias comportam esses corpos, assim como os momentos em que a gente se encontra com a cultura escrita. Portanto, psicologicamente para todos e socialmente para os que não têm recursos sociais, culturais, econômicos, tecnológicos, há, em realidade, uma premência dessas instituições, uma necessidade, já que elas permitem tanto o encontro entre os indivíduos como o encontro dos indivíduos com os livros. Assim sendo, essas instituições como a escola e a biblioteca limitam e compensam em certa medida os efeitos da desigualdade social.

Luzmara Curcino: Entre os lugares de convivência e de sociabilidade leitora, encontra-se o da livraria. A pandemia, em si, é uma crise, como também amplifica várias crises. Em seu mais novo livro editado aqui no Brasil, "Um mundo sem livros e sem livrarias?", o senhor dedica parte dele à reflexão sobre a situação atual das livrarias. O senhor poderia retomar essa reflexão e nos falar de como esse "espaço" público, simbólico, de encontros, que faz parte da formação letrada de gerações de leitores, se encontra. A livraria tal como a conhecemos vai sobreviver? E que papel a seção de livros infantis e juvenis desempenharia nessa sobrevivência comercial das livrarias? Com o risco de fechamento das livrarias, o que as novas gerações perderiam, sem nem sequer ter conhecido? O que nós, como sociedade, perdemos quando uma livraria fecha suas portas?

Roger Chartier: Por um lado, podemos adotar o argumento que apresentamos relativo às bibliotecas, porque como você mesma lembrou, as livrarias também são lugares públicos, de sociabilidade, de encontro, de troca de experiência e de conhecimento, onde autores e leitores se encontram para a apresentação de um livro, para sua discussão. As livrarias são também, por isso, lugares de formação dos leitores. Elas são enfim um espaço de debate e, nesse sentido, a pólis onde circula a palavra, no sentido antigo, de uma comunidade cívica. As livrarias são também o espaço onde se dá visibilidade à pluralidade e à diversidade da cultura escrita, com suas estantes de ficção, de literatura de viagem, de literatura infantil. Nelas, em suas estantes, assim como nas estantes de bibliotecas, nos deparamos com uma visibilidade espacial da cultura escrita, que atua na aprendizagem da ordem dos livros e dos discursos. Na livraria, se pode ver, imediatamente, a diferença editorial entre coleções, séries, através da própria materialidade dos livros. Não sem razão, as livrarias organizam seu acervo de modo a produzir um roteiro pelo qual segue o leitor, comprador potencial, que pode tanto encontrar o que buscava como também ser surpreendido e encontrar o que não buscava. A livraria equivale, portanto, às bibliotecas que permitem livre acesso aos livros. A livraria é a instituição que dá visibilidade à lógica mais fundamental do mundo impresso, que é a lógica espacial, topográfica, territorial. Os livros na livraria, dispostos em seus segmentos, são apresentados como territórios acolhedores de viajantes que Ihes proporcionam descobertas, surpresas, experiências e encontros. Diferentemente 
dessa disposição espacial de bibliotecas e livrarias, o que dá margem ao encontro fortuito do que não se buscava, no mundo digital a busca de livros obedece a uma lógica totalmente diferente, temática e algorítmica, segundo a qual se encontra o que se busca pelo recurso a palavras-chave. Esta é uma organização totalmente diferente daquela do saber ou do prazer. Na livraria os livros estão ao alcance do olhar e das mãos do leitor-cliente favorecendo a leitura como peregrinação, como viagem, como caça furtiva, para empregarmos a imagem construída por Michel de Certeau ${ }^{15}$. Sendo isso o que caracteriza a livraria, seria uma pena o desaparecimento desse espaço.

O diagnóstico contemporâneo a esse respeito é um pouco ambivalente. Por um lado, muitas livrarias fecharam e continuam fechando, antes ou durante a pandemia. A pandemia intensificou uma situação anterior de fragilidade e de viabilidade econômica da livraria. Em Paris, 30\% das livrarias desapareceram entre 2000 e 2015. Acredito que essa porcentagem é ainda mais preocupante hoje. Em geral, ficamos sabendo o que ocorre nas grandes cidades e com as grandes livrarias. A maioria fechou as portas ou fechará em breve, seja em Nova lorque, seja no Rio de Janeiro, enfim, em todas as partes do mundo. As razões são bem conhecidas: a concorrência desigual das vendas online de livros, particularmente da Amazon; a inflação dos aluguéis dos prédios nos centros das cidades; e, finalmente, tal como vimos discutindo, essa espécie de afastamento, de uma parte da população, particularmente das classes mais jovens, no que diz respeito à leitura de livros impressos. É com base nessa convergência de fatores econômicos, comerciais e culturais que se pode explicar a fragilidade das livrarias e seu progressivo desaparecimento.

Por outro lado, e nisso reside a ambivalência a que me referi, há indícios positivos que nos ajudam a lidar com esse diagnóstico mais pessimista que apresentei a pouco. O primeiro deles é uma relativa vitalidade de um tipo específico de livrarias, que não somente resistiram como também ressurgiram mais recentemente: aquele das livrarias independentes, locais, que se caracterizam por seu forte vínculo com uma clientela específica, bem conhecida e relativamente fiel. Em vários países é possível se deparar com casos semelhantes dessas livrarias, não necessariamente pequenas, que fazem parte do tecido social local, e que assim podem resistir mais que outros tipos de livrarias, localizadas nos centros das grandes cidades. O segundo indício positivo da sobrevida das livrarias, no atual cenário pandêmico, é aquele dos países que decidiram interromper o isolamento social, o que gerou um importante afluxo dos clientes nas livrarias. Há muito, os livreiros na França, como também em toda Europa, não viam tamanho sucesso comercial como nos meses que sucederam ao seu fechamento compulsório. Isso não significa que essa demanda e esse afluxo vão se manter e perdurar. No entanto, isso demonstra que havia, por parte dos leitores um sentimento de frustração e um desejo de compensação o mais imediato possível.

O que se pode depreender, em todo caso, tanto entre os diagnósticos tristes quanto entre aqueles felizes, é que os leitores que frequentam e compram livros nas livrarias são leitores que leem livros impressos e são leitores que leram, no último ano, pelo menos 1 livro. São, portanto, leitores de outra geração. Eles não fazem parte da geração dos digital natives, eles não são wreaders, palavra inglesa formada por partes dos verbos write e read, palavra adequada para definir o uso da escrita no mundo digital das redes sociais, onde se lê para escrever, se escreve lendo, e onde há um entrelaçamento entre as duas práticas tradicionalmente diferentes, quanto ao tempo, aos objetos e aos lugares.

Assim, os leitores que asseguram a sobrevida das livrarias pertencem à geração que hoje ainda é, talvez, dominante numericamente, mas que estão diminuindo progressivamente. A aposta fundamental é a de saber se esses digital natives, se esses wreaders vão ou não manter não somente a

15 Certeau, 1994. 
leitura dos livros impressos, como também a compra desses livros impressos junto às livrarias físicas. Esta é uma pergunta sem resposta. O problema fundamental nessa questão é sabermos em que medida essa geração, cujas práticas são moldadas em conformidade com as práticas do universo digital, pode ser influenciada pelas palavras, exemplos e práticas de seus professores, pais e amigos em relação a outras práticas. Não se pode perder de vista as possibilidades de fazer algo a esse respeito. Não é porque nasceram em um mundo amplamente digital, ou porque exercem suas práticas exclusivamente digitais, que com um certo esforço de nossa geração não possamos afetar outras gerações, fazendo-a se questionar sobre seus comportamentos. Nós também não nos fazíamos perguntas sobre nossas ações, porque era para nós normal ir comprar um livro na livraria ou lê-lo na biblioteca. Esse saber deve ser ensinado, por se tratar de uma realidade totalmente nova. Podemos nos perguntar se os discursos podem modificar as práticas. Eu não saberia dizer (risos).

Luzmara Curcino: Eu espero que sim! Espero que nossa voz em defesa da pluralidade das práticas e dos meios de leitura tenha força suficiente para subverter, ainda que em parte, certas lógicas totalizantes estabelecidas com a expansão das tecnologias digitais, e que a saudade desses espaços, dessas instituições e de seus objetos, seja uma emoção mobilizadora, capaz de manter e de sustentar a existência dessas instituições na sua realidade espacial. Gostaria de finalizar essa nossa conversa com uma última questão. No balanço geral dessas mudanças que estamos testemunhando hoje no mundo da escrita e da leitura, o senhor tende a ver o copo mais cheio ou mais vazio?

Roger Chartier: Algumas vezes me parece que não temos copo! São os próprios copos que desapareceram! Imaginando que ainda temos copos, por um lado, o vejo meio vazio, já que vivenciamos uma situação preocupante, que enfatizamos em diferentes circunstâncias desta nossa conversa, relativa aos perigos para o conhecimento e para a democracia frente a essa proliferação de inverdades, mentiras e falsificações e, ainda mais preocupante, frente às condições favoráveis de crença nessas falsificações. Essa é uma primeira preocupação, e por si só motivo suficiente de ansiedade, diante da consciência do perigo para o conhecimento e do medo do risco de deterioração da democracia. Sendo fiéis à ideia da pólis antiga na Grécia, segundo a qual se afirma existir uma relação necessária entre conhecimento e deliberação, entre saber e decisão política, talvez estejamos diante de um copo cheio, mas cheio de veneno, frente aos ataques coordenados ao conhecimento verdadeiro e à democracia.

No entanto, ao mesmo tempo, um efeito inesperado da pandemia parece ter sido a maior consciência desses perigos, um maior sentimento de frustração, de ausência, de carência conjugados à percepção de uma mutilação da vida em sua completude. Com isso, tendo a achar que há, de certo modo, uma tomada de consciência, uma percepção mais aguda desses perigos. Designar e denunciar essas falsificações, nos valendo de instrumentos que nos permitam demonstrá-las como tal, e afirmar os riscos que elas representam para a democracia é, de certo modo, um indício da saúde do funcionamento democrático. Logo, nem tudo está perdido. Esse copo também está cheio. A maior consciência desse funcionamento de construção dos textos e do uso das redes sociais para a difusão de mentiras pode conduzir a uma mobilização dos cidadãos, a uma mobilização que exija políticas públicas capazes de proteger as instituições de transmissão do conhecimento verdadeiro e de fomento do debate democrático.

Diante do desmantelamento das principais instituições que zelam pelo conhecimento e pela democracia, por meio da supressão ou sucateamento de políticas públicas voltadas para escola, para a promoção da leitura, para a expansão das bibliotecas, para a proteção das livrarias e das editoras, é preciso tomar consciência e agir não somente como indivíduo, mas também como cidadão, de modo a atuar para que o destino coletivo da pólis seja o melhor ou o menos pior possível. 
Entre as ações variadas possíveis, é responsabilidade de cada um de nós como leitores e como consumidores de livros e outros bens culturais de resistir à facilidade do 'click', porque com um 'click' se pode comprar um livro sem ir à livraria, se pode ler um jornal sem comprar a edição impressa, se pode pensar que ler um livro digital é algo idêntico a ler o "mesmo" texto na sua forma impressa. Evidentemente, no tempo da pandemia essa ilusão foi útil e proveitosa, por ter permitido manter a atividade intelectual, cultural, o prazer e o saber. Depois da pandemia, não poderemos mais nos furtar da reflexão individual, da tomada de consciência e da necessária resistência a essas facilidades, adotando como princípio a aquisição de livros nas livrarias, assumidas por nós como uma das instituições fundamentais do tecido social e cidadão, tal como a biblioteca.

É necessário mantermos uma relação com os leitores do passado que não leram frente às telas. Para isso é preciso defender o jornal, a imprensa, compreendendo as diferentes lógicas implicadas na busca de um texto por palavras-chave, que acessamos pelas telas, bem distinta da busca de uma informação ao longo das páginas do jornal, de um livro, no espaço da livraria ou nas estantes de bibliotecas. Esse esforço de resistir ao 'click' pode se converter em um prazer. Dessa maneira, o copo até pode não estar totalmente cheio, mas com certeza nos reservará alguma fonte de prazer.

Luzmara Curcino: Resistiremos coletivamente ao "click", e manteremos o copo cheio de esperança, e por que não de algo mais (risos). Gostaria de agradecer novamente ao professor por ter aceitado o convite para esta conversa, o que foi para mim um enorme prazer. Todos nós esperamos poder revê-lo o mais breve possível, fora das telas, pessoalmente, aqui no Brasil. Sei que sentimento equivalente é compartilhado pela Professora Ana Maria Esteves Bortolanza, a quem também agradeço ao convite para realizarmos esta entrevista e a quem passo a palavra para as considerações finais.

Ana Maria Esteves Bortolanza: Esta foi, sem dúvida, uma manhã para nós, e uma tarde aí para o senhor, muito agradável e plena de generosidade e de reflexões. Foi muito bom acompanhar esta entrevista, na condição de coordenadora deste dossiê temático. Pude me deliciar com essa circunstância tão dialógica. Reitero os agradecimentos, em meu nome, em nome da Revista Brasileira de Alfabetização (RBA), a ambos, ao professor Roger Chartier, a quem tanto admiramos, e a minha colega, professora Luzmara Curcino, que se dispuseram prontamente a realizar esta entrevista para este dossiê. Também espero poder encontrá-lo aqui no Brasil, nos eventos, tão logo essa pandemia o permita, ocasião em que o senhor poderá autografar esse seu livro que acaba de ser publicado "Um mundo sem livros e sem livrarias?", e para divulgarmos a publicação desta sua entrevista.

Roger Chartier: Com grande prazer!

\section{Referências}

BENJAMIN, Walter. A obra de arte na era de sua reprodutibilidade técnica. In: ADORNO et al. Teoria da Cultura de massa. Trad. de Carlos Nelson Coutinho. São Paulo: Paz e Terra, 2000. p. 221-254.

CERTEAU, Michel. A invenção do cotidiano - artes de fazer. Petrópolis: Vozes, 1994.

CHARTIER, Roger. Verdade e prova: retórica, literatura, memória e história. CURCINO, Luzmara; SARGENTINI, Vanice; PIOVEZANI, Carlos. (orgs.). Discurso e (pós)verdade. São Paulo: 2021.

CHARTIER, Roger. Ler sem livros. In: Revista Linguasagem, São Carlos, v.32, CURCINO, Luzmara; OLIVEIRA, Jéssica; VARELLA, Simone. (orgs.). Número temático. Discursos sobre leitores e leitura: suas representações simbólicas como tema de pesquisa. dez/2019, p. 6-17. Disponível em: http://www.linguasagem.ufscar.br/index. php/linguasagem/article/view/655/396. Acesso em 22 de abril de 2021. 
CHARTIER, Roger. Do palco à página: Publicar teatro e ler romances na Época Moderna - séculos XVI-XVIII. São Carlos: EdUFSCar, 2017.

CHARTIER, Roger. Cardenio entre Cervantes e Shakespeare: história de uma peça perdida. Rio de Janeiro: Civilização brasileira, 2012a.

CHARTIER, Roger. O Dom Quixote de Antônio José da Silva, as marionetes do Bairro Alto e as prisões da Inquisição. Sociologia\&Antropologia, Rio de Janeiro, v. 2, n. 3, p. 161-181, Jun. 2012b. Disponível em: http:// www.scielo.br/scielo.php?script=sci_arttext\&pid=S223838752012000300161\&lng=en\&nrm=iso. Acesso em 22 de abril de 2021. http://dx.doi.org/10.1590/2238-38752012v237.

CHARTIER, Roger. A aventura do livro: do leitor ao navegador. São Paulo: Editora UNESP/Imprensa Oficial, 1999.

CURCINO, Luzmara. Os sentidos do olhar: o leitor e a escrita da mídia nas sociedades contemporâneas. In: PIOVEZANI, Carlos; CURCINO, Luzmara; SARGENTINI, Vanice. Discurso, Semiologia e História. São Carlos: Claraluz, 2011.

GUEREÑA, Jean-Louis. ¿Un icono nacional? La instrumentalización del Quijote en el espacio escolar en el primer tercio del siglo XX. Bulletin hispanique, 110-1, 2008. (p. 145-190).

LOBATO, Monteiro. Dom Quixote das crianças. São Paulo: Brasiliense, 2019.

LAJOLO, Marisa; ZILBERMAN, Regina. Literatura infantil brasileira: uma nova outra história. Curitiba: PUCPR, 2017. E-book.

ROSA, Harmut. Aceleração. A transformação das estruturas temporais na Modernidade. São Paulo: Editora UNESP, 2019.

Recebido em: 30/04/2021

Aceito em: 28/05/2021 